\title{
Macroeconomics, Firm-Specific Factors and Stock Liquidity: An Empirical Evidence from Jordan
}

\author{
Wasfi A. Al Salamat ${ }^{1}$ \\ ${ }^{1}$ Department of Banking and Financial Sciences, Faculty of Economics and Administrative Sciences, The Hashemite \\ University, Zarqa, Jordan
}

Correspondence: Wasfi A. Al Salamat, Assistant Professor of Finance, PhD., Department of Banking and Financial Sciences, Faculty of Economics and Administrative Sciences, The Hashemite University, Zarqa, Jordan.

Received: September 2, 2016

Accepted: September 26, $2016 \quad$ Online Published: October 8, 2016

doi:10.5430/ijfr.v7n5p110

URL: http://dx.doi.org/10.5430/ijfr.v7n5p110

\begin{abstract}
The aim of this study is to identify the macroeconomics and firm-specific determinants of stock liquidity in the context of Jordan over the period (2007-2014). As a sample, all industrial firms listed in the Amman Stock Exchange are taken for analysis. Unbalanced panel data (cross-sectional and time series) is used to obtain the results. The results show that the stock liquidity is positively affected by earnings per share, interest rate, gross domestic product, leverage, and the size of the firm while negatively affected by the ratio of the market value per share to the book value per share, inflation rate, and the return on assets.
\end{abstract}

Keywords: stock liquidity, macroeconomics factors, firm-specific factors, industrial firms, panel data, ASE

\section{Introduction}

Financial markets play an important role in the most of the developed and developing countries alike for being one of the fiscal policy instruments used in increasing the local savings and a tool for attracting foreign investments as well as its importance in financing economic development plans, especially that most of the countries are suffering from a continual deficit in their public budgets, which prompt these countries looking for a non-sovereign financial resources to finance their development plans, financial markets have become one of the most important tools that are used for such developmental purposes. Moreover, the financial markets can improve the economic growth in both emerging markets and developed ones as well where investors can buy and sell securities and get gains via exchanges. Financial market is considered a main source of funding of firms expansion and government expenditure.

There is no doubt that the increasing of liquidity depends on the stock turnover, where the greater the number of times the turnover of the stock, the sufficient liquidity able to make the financial market to be effective. In order to achieve that, recent years have witnessed continuous efforts in the majority of countries to develop their financial markets and to construct the sound investment climate for them in order to attract investments for them, most of countries, especially developing ones have achieved varying degrees of success in this difficult task.

The cost of capital could be reduced by deeper and increasing stock market liquidity. In addition, the individual stock liquidity could be increased by deeper and increasing stock market liquidity. In addition it is considered an important factor in determining the success of public offering, decreasing the cost of raising capital and the risk for investors as well as market makers. Further, liquidity can decline the transaction costs.

Liquidity is considered one of the positive characteristics of competitive markets. Moreover, liquidity is playing a very significant role in share pricing, so investor focusing on this point in finding appropriate market when he wants to sell his shares (Chai et al., 2010). The liquidity of stock market is considered essential to the stability of financial system because the ability of a liquid market to absorb systemic shocks is high. It can be defined as the ability of market to absorb a big volume of trades with no severe stock price volatility (O'hara, 1998).

The liquidity is very significant for markets to operate effectively. Further market liquidity makes the distribution of sources more efficient via the allocation of risk and capital efficiently and by making the money supply and financial stability effective.

Due to the price risk investors with higher stock liquidity will earn more than investors with lower stock liquidity. Furthermore, by raising the stock liquidity, firms can decrease the cost of capital (Kumar and Misra, 2015). 
Investors or portfolio managers during the crises or recession usually reorganize their portfolios to decline the risky and high liquid assets. This action is called a flight to quality and a flight to liquidity.

The aim of this study is to identify the factors (macroeconomics and firm-specific) that determine the stock liquidity for all industrial firms listed in the Amman Stock Exchange over the period from 2007 to 2014.

\subsection{The Importance of Study}

The importance of this study is due to being treated the subject of great importance due to the urgent need of Jordan to additional sources of funding to finance its development needs and covering the deficit in its budget. There is no doubt that the turnover ratio (the number of shares traded over the number of subscribed shares) has a clear impact on increasing liquidity in financial market where the greater the number of shares traded, the more the liquidity. Further, liquidity plays an important role in increasing the efficiency of financial market, so it requires identification the factors affecting the trading activity and stock turnover in order to make this market more effective and attractive to investors, especially after investment became unlimited to national contributions through savings achieved at the level of individuals and public or private institutions, where it became based on the attraction of global market in the era of economic blocs and multinational corporations occupied an important position in the international direct investments. Moreover, the importance of study comes from the importance of factors affecting trading activity and stock turnover in the Amman Stock Exchange, and therefore, this study is only an empirical attempt in this direction added to the attempts that are made in this area.

\section{Literature Review}

Stock liquidity has a huge interest of firms' managers, investors, government, and researchers. Liquidity, in general, and stock liquidity, in particular, is a key topic in finance, defines as the ability of investors to purchase or sell a big amount of securities readily and without significant loss. Moreover, the factors affecting the stock liquidity have been examined by many researchers since the 1980s. The study of Chordia et al. (2001) is considered the best one.

Amihud and Mendelson (1989) show that investors who have lower liquidity shares require higher rate of return in order to reimburse them for higher transaction costs. Accordingly, the stock will inversely affected making it costly and to be less attractive to them. The ability of the company to raise its stock liquidity can be increased by cross listing which leads to reduce the price of its shares and makes the share more desirable to investors in primary and secondary markets as well. Furthermore, remaining all things the same, when liquidity increases, it could lead to reduce the cost of capital as a result of decreasing the trading costs and for that reason the required illiquidity premium will be decreased (Brennan et al., 1998 and Jacoby et al, 2000).

Amihud and Mendelson $(1988,2000)$ argue that firm can decrease the cost of raising capital by improving the liquidity of its stock. Liquidity is very important in the valuation of stock, therefore it is worth for firm to develop approaches for enhancing the stock liquidity. So it is so significant to examine the determinants of stock liquidity for industrial firms listed in the Amman Stock Exchange. Moreover, Weston et al. (2005) suggest that the cost of raising capital of firm could be decreased by enhancing the liquidity of its stock. In addition, the association between liquidity and the cost of capital is analyzed by Amihud and Mendelson (1986). The investors prefer more liquid markets than less liquid ones because they can transfer their ownership readily.

Amihud and Mendelson (1988) suggest some financial strategies which can be used by firm to improve its stock liquidity like initial public offering, issuing shares with customized characteristics, make its stock to be listed on organized exchanges, make the public to be informed regarding its inside information, and make its capital to be decentralized.

It is important to understand liquidity and to examine its role and influence in capital markets. Grecuhina and Timofejeva (2008) suggest that the quality of markets in general and stock market specifically are affected by liquidity and some other factors like information asymmetry and disclosure. Furthermore, stock liquidity could be influenced by lower liquidity which lead to increase the expected rate of return which in turn increase the cost of capital. On the other hand, the higher the stock liquidity, the lower the rate of return and as a result decreasing the cost of capital and increasing the market value (Moghadas, 2011). Moreover, firm's capital structure decisions could be influenced by stock liquidity. Accordingly, the motivation of firms having more liquid stocks is greater than firms having less liquid assets (Udomsirikul et al., 2011).

In the 1980s some studies find a positive relation between stock liquidity and its price which lead to reduce the cost of raising capital. Therefore firms try to develop their stock liquidity. The illiquidity index is used by Amihud (2002) to explore the effect of market conditions on the return of stocks by taking a sample of firms listed with the NYSE. 
The association between stock liquidity and financial leverage is examined by some researchers (e.g., Lesmond, O'Connor and Senbet, 2008, and Lipson and Mortal, 2009). Lesmond, O'Connor and Senbet (2008) suggest that information asymmetry and as a result of that the liquidity cost will be increased by increasing the ratio of debt to the ratio of equity in the firm's capital structure. As a sample, some non-financial firms are taken to investigate the above relation. They choose levered firms and they find that these firms can reduce the cost of raising capital as a result of reducing the possibility of trading depending on inside information which achieved by increasing its stock liquidity. However, Lipson and Mortal, 2009) propose that the rate of return required on stock is decreased as a result of increasing its liquidity which then decrease the cost of raising capital as a whole. Therefore unlevered firms try to increase the ratio of stocks to bonds in their capital structure.

Chordia et al. (2001) examine the effect of market return, market volatility, and interest rate on stock liquidity and trading activity. Moreover, liquidity is affected by gross domestic product and unemployment at the time of declarations.

Chordia et al. (2005) demonstrate moderate relationship between monetary policy and stock liquidity. On contrast, Goyenko and Ukhov (2009) show a significant relationship between monetary policy and stock liquidity for U.S. listed firms.

Hansen and Sungsuk (2013) examine the effect of stock liquidity on the value of the firm for a sample of firms listed on the Indonesian Stock Market. Panel data (cross-sectional and time series) is used to analyze the relationship. The results show that there is a positive relationship between stock liquidity and the following variables: earnings before interest and taxes, the ratio of earnings before interest and taxes to stock price, financial leverage, and earnings before interest and taxes to total assets.

Spindt et al. (2007) investigate the relation between dividend payout ratio and stock liquidity. The results show a negative relationship between dividends and stock liquidity where investors try to get high cash dividends in illiquid stocks. On the other hand, Brockman et al. (2008) examine the relationship stock liquidity and payout decisions for a sample of firms listed on the NYSE. The results demonstrate that the firm prefers to repurchase its shares instead of paying dividends in the case of high market liquidity.

The liquidity of stock can be influenced by some variables such as the size of the firm, and the liquidity of market as a whole. Shuenn (2007) shows that stock liquidity is positively affected by the size of the firm.

To the best of the author's knowledge, this is the first study carried out in the context of Jordan identifying the determinants of stock liquidity on the two levels (macroeconomics and firm-specific). Further, this study extended the models used in the previous studies by including the following variables (interest rate, inflation, GDP, money supply, market to book ratio, leverage, earnings per share, size, payout ratio, and return on assets) together in the same model.

\section{The Methodology of Study}

\subsection{The Population and Sample of the Study}

The population of this study consists of all industrial firms listed in the Amman Stock Exchange over the period from 2007 to 2014 while the sample of this study varies from year to another from 62 firms in one year to 69 firms in another year according to the data availability for each firm to identify the determinants of stock liquidity.

Regarding the number of firms that included to identify the determinants of stock liquidity, firms enter and leave the sample each year, so, the number of firms differs from year to another (unbalanced data), and thus there is no survival bias in the data (e.g. Morgan and Thomas, 1998; McManus et al., 2004). Finally, the number of observations that included to identify the determinants of stock liquidity is 515 .

\subsection{Statistical Approach}

Firstly, we will use summary statistics such as minimum, maximum, mean, and standard deviation in order to describe the features of all variables that are used in the analysis. The unbalanced panel data (cross-sectional and time series) is used to identify the determinants of stock liquidity. Further, the correlation matrix is used to test the strength and the direction of the relationship between each pair of independent variables as well as between each explanatory variable and dependent variable, and to detect the expectance of multicollinearty problem. Variance inflation factor (VIF) can be used in addition to correlation matrix to detect the problem of collinearty. Durbin- Watson is also used to detect the problem of autocorrelation between errors. In addition, $t$ test and $F$ test are used for checking the significance of the multiple regression. On one hand, $t$ test is used to test if the relationship between each independent variable individually is significant or not, on the other hand, $F$ test is used to check the overall significance. 
Therefore, the quantitative methods are used to examine the previous relationships. Excel spreadsheet is used for entering data and constructing (preparing) variables while both SPSS statistical software package (version 22) and STATA are used for running the multiple regressions in order to get the results.

\subsection{Variables Definition}

The variables which used to identify the determinants of stock liquidity for all industrial firms listed in the Amman Stock Exchange over the period from 2007 to 2014 are based on previous researches (e.g. Amihud and Mendelson, 1989; Chordia et al., 2005; Spindtet al., 2007; Shuenn, 2007; Lipsona and Mortal, 2009; and Alnaif, 2014).

\subsubsection{Dependent Variable}

\section{Stock Liquidity}

The value traded is used in this study as a dependent variable. It can be found by taking the natural logarithm of the total value traded during the year. This is represented algebraically as follows.

$$
V T i, t=L N(V T i, t)
$$

Where, $V T$ denotes the Value Traded for firm $i$ in year $t$.

\subsubsection{Independent Variables}

Interest rate is defined as the interest rate on loans.

Inflation is found by dividing the difference between the consumer price index in the current year and the consumer price index in the previous year over the consumer price index in the previous year. This is represented algebraically as follows.

$$
I N F t=(\text { CPIt }- \text { CPI } t-1) \div \text { CPI } t-1
$$

Where CPIt, CPI $t-1$ are denote the consumer price index in the current year and the previous year, respectively.

\section{Money Supply}

Money supply is used as a proxy for monetary policy. This variable can be found by taking the money supply with the narrower term (M1) which can be calculated by taking the growth in money supply. This is represented algebraically as follows.

$$
M 1 t=(M 1, t-M 1, t-1) \div M 1, t-1
$$

Where $M 1, t, M 1, t-1$ are denote the money supply in the current year and the previous year, respectively.

\section{Gross Domestic Product (GDP)}

This variable is found by dividing the difference between the Gross Domestic Product in the current year and the Gross Domestic Product in the previous year over the Gross Domestic Product in the previous year. This is represented algebraically as follows.

$$
G D P t=(G D P t-G D P t-1) \div G D P t-1
$$

Where GDP $t, G D P t-1$ are denote the Gross Domestic Product in the current year and the previous year, respectively.

\section{Market to Book ratio (MB)}

This variable can be found by dividing the market price per share over the book value per share. This is represented algebraically as follows.

$$
M B i, t=\text { Market valuei, } t \div \text { Book valuei, } t
$$

\section{Financial leverage (LEV)}

To calculate this variable, total debt (total liabilities) is divided by total assets for each year. This is represented algebraically as follows.

$$
L E V i, t=\frac{\sum T L}{\sum T A}
$$

Where $\sum \mathrm{TL}, \sum \mathrm{TA}$ are denote the total liabilities and total assets in the current year, respectively.

\section{Earnings per share (EPS)}


To calculate this variable, the net income is divided by the number of shares outstanding. This is represented algebraically as follows.

$$
E P S i, t=N I \div \# \text { Shares }
$$

Where NI, \# Shares are denote the net income and the number of shares outstanding in the current year, respectively. Size is defined as the natural logarithm of the market capitalization. This is represented algebraically as follows.

$$
S i, t=L N(M C i, t)
$$

Where $M C$ denotes the market capitalization in the current year for firm $i$.

\section{Payout ratio (PR)}

This variable can be computed by dividing the cash dividend paid to shareholders by net income. This is represented algebraically as follows.

$$
P R i, t=D I V i, t \div N I i, t
$$

Where, DIVi,t,NIi, $t$ denote the cash dividends and the net income, respectively.

\section{Return on assets (ROA)}

To compute this variable, net income for each firm is divided by the total assets. This is represented algebraically as follows.

$$
R O A i, t=N I i, t \div T A i, t
$$

Where, $N I i, t, T A i, t$ denote the net income and total assets for firm $i$ and year $t$, respectively.

\subsection{Study Hypotheses}

Prior research proposes that the stock liquidity could be affected by some macroeconomics and firm-specific factors such as: interest rate, inflation, monetary policy, GDP, market to book ratio, earnings per share, size, dividends, financial leverage, return on assets (e.g. Amihud and Mendelson, 1989; Chordia et al., 2005; Spindtet al., 2007; Shuenn, 2007; Lipsona and Mortal, 2009; and Alnaif, 2014). So, we can form one hypothesis for the relationship between each above variable with stock liquidity as follows:

H01: there is no relationship between the interest rate and the stock liquidity for all industrial firms listed in the Amman Stock Exchange.

H02: there is no relationship between the inflation and the stock liquidity for all industrial firms listed in the Amman Stock Exchange.

H03: there is no relationship between the monetary policy and the stock liquidity for all industrial firms listed in the Amman Stock Exchange.

H04: there is no relationship between the GDP and the stock liquidity for all industrial firms listed in the Amman Stock Exchange.

H05: there is no relationship between market to book ratio and the stock liquidity for all industrial firms listed in the Amman Stock Exchange.

H06: there is no relationship between earnings per share and the stock liquidity for all industrial firms listed in the Amman Stock Exchange.

H07: there is no relationship between size and the stock liquidity for all industrial firms listed in the Amman Stock Exchange.

H08: there is no relationship between dividends and the stock liquidity for all industrial firms listed in the Amman Stock Exchange.

H09: there is no relationship between financial leverage and the stock liquidity for all industrial firms listed in the Amman Stock Exchange.

H10: there is no relationship between return on assets and the stock liquidity for all industrial firms listed in the Amman Stock Exchange.

\subsection{The Study Model}

To identify the determinants of stock liquidity for all industrial firms listed in the Amman Stock Exchange, we will use following regression model based on (Amihud and Mendelson, 1989; Chordia et al., 2005; Spindtet al., 2007; Shuenn, 
2007; Lipsona and Mortal, 2009; and Alnaif, 2014). This model is extended by combining the following independent variables together (interest rate, inflation, monetary policy, GDP, market to book ratio, earnings per share, size, dividends, financial leverage, return on assets).

$$
\begin{aligned}
& V T i, t=\beta_{0}+\beta_{1} I R t+\beta_{2 G D P t}+\beta_{3 I N F L t}+\beta_{4} B M i, t+\beta_{5} L E V i, t \\
& +\beta_{6} L n S i, t+\beta 7 E P S i, t+\beta 8 P R i, t+\beta 9 R O A i, t+\beta 10 M 1+E i, t
\end{aligned}
$$

\section{The Results of Study}

\subsection{Summary Statistics}

Table 1 shows the minimum, maximum, mean, and standard deviation of all variables that determine the stock liquidity for industrial firms listed in the Amman Stock Exchange over the period from 2007 to 2014.

Table 1. Descriptive Statistics of dependent and independent variables for all firms (2007-2014)

\begin{tabular}{r|rrrrr} 
Variable & Obs & Mean & Std. Dev. & Min & Max \\
\hline IV & 515 & 6.12222 & 1.186929 & 2.135133 & 9.426301 \\
IR & 515 & 8.993845 & .2252106 & 8.67 & 9.48 \\
INE & 515 & .0532641 & .0421827 & -.007 & .149 \\
GDP & 515 & .035332 & .0134743 & .023 & .06 \\
M1 & 515 & .0937516 & .05036 & -.00831 & .166036 \\
\hline MB & 515 & 1.427492 & 1.070597 & .2225147 & 7.473667 \\
EPS & 515 & .0812501 & .4275243 & -.6573912 & 3.737368 \\
IEV & 515 & .3389661 & .2061997 & .0039982 & .9447334 \\
PR & 515 & .4187916 & .9633088 & -1.60344 & 9.983477 \\
S & 515 & 16.62396 & 1.354353 & 13.6287 & 20.92479 \\
\hline ROA & 515 & -.0004484 & .1118279 & -.9687077 & .4329937
\end{tabular}

As can be seen from Table 1, the interest rate on loans (IR) is the first independent variable. Its values range from a minimum of 8.67 to a maximum of 9.48 . It has mean value equal to 8.99 , and standard deviation equal to .225 , implying that slight variations regarding interest rate from year to another over the period of the study.

Inflation is the second explanatory variable. It varies from -.007 to .149; implying that the consumer price index in one year is less than the consumer price index in the previous year, whereas its mean is .05, and standard deviation is .04, suggesting slight variations with respect to inflation rate from year to another over the period of the study.

The gross domestic product (GDP) ranges from .023 to .06, with mean of .035 , and standard deviation of .013, which means slight variations with respect to gross domestic product (GDP) from year to another over the period of the study.

It can also be seen from the above table that the money supply (M1) varies from -.00831 showing that the money supply in one year is smaller than the money supply in the previous year, to .166, with mean of .09, and standard deviation of .05, suggesting slight variations with respect to money supply from year to another over the period of the study.

The market to book value per share (MB) ranges from .22 implying that at least one industrial firm has market stock price less than its book value to 7.47 , with mean of 1.43 , means that the market stock price is greater than its book value for industrial firms listed in the Amman Stock Exchange over the period (2007-2014), on average) and standard deviation of 1.07, which means high variations among industrial firms with respect to market to book value per share (MB) over the period of the study.

Earnings per share (EPS) ranges from -.657 indicating that some industrial firms suffering from losses in one year at least, to 3.7 with mean of .08 showing that, on average, the share of each stock of profits for industrial firm is about .08 JOD, and standard deviation of .43 which means high variations among industrial firms with respect to Earnings per share (EPS) over the period of the study. 
Financial leverage has values range from .004 to .945 , implying that the ratio of total liabilities to total assets is very small for some firms, indicating that some firms depend heavily on issuing equity to finance their assets, while total liabilities is close to total assets for some firms, implying that some firms rely heavily on debt to finance their assets. Its mean value equal to .339 , which means that the industrial firms listed in the Amman Stock Exchange, on average, do not depend highly on debts to finance their assets, and standard deviation of .21, showing that high variations among industrial firms with respect to their financial leverage.

The dividend payout ratio (PR) ranges from -1.6 indicating that some firms pay cash dividends while suffering from losses, to 9.98 suggesting that some firms pay cash dividends about 10 times of their earnings. Its mean of 0.42 implying that industrial firms , on average, pay about half of their profits as cash dividends over the period of study, and standard deviation of 0.96 , showing that high variations among industrial firms with respect to their dividend payout ratio (PR).

The range of the size of the firm (S) varies from 13.63 (the natural logarithm of total assets) to 20.92, its mean of 16.62, and standard deviation of 1.35, suggesting high variations among industrial firms in their size. Therefore, some industrial firms have huge assets while some ones have small assets over the period of study.

The last independent variable is return on assets. It has a range from -.97 indicating that some industrial firms have losses over the period of study (2007-2014), to .43 implying that each 1 JOD invests in the total assets generate .43 JOD for some industrial firms, with mean of -.0004, and standard deviation of .11 suggesting high variations among industrial firms in their return on assets.

The traded value (the natural logarithm of the traded value) is the dependent variable ranges from 2.14 to 9.42 , with mean of 6.12 , and standard deviation of 1.19 , showing high variations amongst the industrial firms in their traded value.

\subsection{Hypothesis Testing}

Before starting to talk about the testing of hypotheses, the correlation coefficients between the explanatory variables will be provided to give you an idea about the strength and the direction of the relationship between each two independent variables, as well as with the dependent one. In addition, correlation coefficient matrix can be used to detect the problem of Multicollinearity.

Table 2. Correlation coefficients of dependent and independent variables

\begin{tabular}{|c|c|c|c|c|c|c|c|}
\hline & LV & IR & INF & GDP & M1 & MB & EPS \\
\hline $\mathrm{LV}$ & 1.0000 & & & & & & \\
\hline IR & 0.2017 & 1.0000 & & & & & \\
\hline INF & 0.1847 & 0.6729 & 1.0000 & & & & \\
\hline GDP & 0.3060 & 0.4166 & 0.6869 & 1.0000 & & & \\
\hline M1 & 0.0846 & 0.3852 & 0.4182 & 0.1378 & 1.0000 & & \\
\hline MB & 0.0064 & 0.0338 & 0.0451 & 0.1364 & 0.0083 & 1.0000 & \\
\hline EPS & 0.2297 & -0.0063 & 0.0203 & 0.0377 & -0.0131 & 0.3200 & 1.0000 \\
\hline $\mathrm{LEV}$ & 0.1502 & -0.0211 & -0.0068 & -0.0398 & 0.0139 & -0.0085 & -0.2295 \\
\hline PR & -0.0793 & -0.0825 & -0.0655 & 0.0087 & -0.1155 & 0.0161 & 0.1074 \\
\hline S & 0.3856 & -0.0088 & -0.0039 & -0.0141 & 0.0143 & 0.0203 & 0.5100 \\
\hline \multirow[t]{2}{*}{$\mathrm{ROA}$} & 0.0985 & -0.0180 & -0.0092 & 0.0561 & -0.0506 & 0.1195 & 0.6689 \\
\hline & LEV & $\mathrm{PR}$ & S & $\mathrm{ROA}$ & & & \\
\hline LEV & 1.0000 & & & & & & \\
\hline PR & -0.1812 & 1.0000 & & & & & \\
\hline S & 0.1158 & 0.0544 & 1.0000 & & & & \\
\hline $\mathrm{ROA}$ & -0.2653 & 0.1992 & 0.4137 & 1.0000 & & & \\
\hline
\end{tabular}

Table 2 shows that the highest correlation coefficient is between the inflation rate and the gross domestic product (GDP) which is positive while the lowest correlation coefficient is between the size of the firm and inflation rate which is negative. Further, it can be seen from Table 2 that there is no correlation coefficient greater than 0.70 which implying 
that there is no Multicollinearity among independent variables as well as with dependent one.

Table 3 provide the variance inflation factor (VIF) which is another way for detecting the problem of Multicollinearity (one of the violations of ordinary least square regression model) for all independent variables that used in the regression model.

Table 3. Variance inflation factor (VIF)

\begin{tabular}{r|rr} 
Variable & VIF & $1 /$ VIF \\
\hline INF & 3.23 & 0.309317 \\
EPS & 2.48 & 0.402681 \\
GDP & 2.07 & 0.482694 \\
ROA & 1.98 & 0.504080 \\
IR & 1.89 & 0.530395 \\
$S$ & 1.56 & 0.639252 \\
M1 & 1.31 & 0.761283 \\
IEV & 1.23 & 0.812483 \\
MB & 1.21 & 0.826025 \\
PR & 1.08 & 0.925717 \\
\hline Mean VIF & 1.81 &
\end{tabular}

Table 3 provides the variance inflation factor (VIF) for all independent variables which used in this study. As can be seen from the above table that there is no variance inflation factor (VIF) for all independent variables greater that 10 or 5 (cut-off points). Therefore, there is no existence to the Multicollinearity problem according to the (VIF).

Table 4 is used to determine which model (fixed or random) is appropriate for analysis according to Hausman test.

Table 4. Hausman test

$$
\begin{aligned}
& \text {. hausman fixed random } \\
& \begin{array}{r|rrrr} 
& \multicolumn{1}{c}{\begin{array}{c}
(\mathrm{b}) \\
\text { fixed }
\end{array}} & \begin{array}{c}
(\mathrm{B}) \\
\text { random }
\end{array} & \begin{array}{c}
(\mathrm{b}-\mathrm{B}) \\
\text { Difference }
\end{array} & \begin{array}{c}
\text { sqrt (diag }\left(V_{-} \text {b-V_B }\right) \\
\text { S.E. }
\end{array} \\
\hline \text { MB } & -.1267322 & -.1213129 & -.0054192 & .0129562 \\
\text { EPS } & .6212483 & .6185749 & .0026734 & .0483487 \\
\text { IR } & .8684088 & .9063269 & -.0379181 & .0318308 \\
\text { INF } & -6.56806 & -6.696664 & .1286042 & .1560137 \\
\text { GDP } & 36.37021 & 36.5321 & -.1618981 & .4145416 \\
\text { LEV } & .6894795 & .7222891 & -.0328096 & .084422 \\
\text { PR } & -.0685266 & -.074301 & .0057744 & .0113995 \\
\text { M1 } & 1.01399 & 1.008999 & .0049916 & .073618 \\
\text { S } & .2619087 & .2720432 & -.0101344 & .0153646 \\
\text { ROA } & -1.499748 & -1.518577 & .0188289 & .1529567 \\
\hline
\end{array} \\
& \mathrm{b}=\text { consistent under Ho and Ha; obtained from xtreg } \\
& \mathrm{B}=\text { inconsistent under Ha, efficient under Ho; obtained from xtreg } \\
& \text { Test: Ho: difference in coefficients not systematic } \\
& \begin{aligned}
\operatorname{chi2}(10) & =(b-B) '\left[\left(V_{-} b-V_{-} B\right)^{\wedge}(-1)\right](b-B) \\
& =\quad 3.29
\end{aligned} \\
& \text { Prob }>\text { chi2 }=0.9739
\end{aligned}
$$


Table 4 shows that the p-value of 0.9739 is more than both significance levels $(0.01$ and 0.05$)$, implying that the random model is more suitable to be used than fixed model according to Hausman test.

Table 5 provides the regression coefficients of all independent variables which used in this study. This table is very important for accepting or rejecting the hypotheses of the study.

Table 5. Regression Coefficients of independent variables (2007-2014)

\begin{tabular}{|c|c|c|c|c|c|c|}
\hline Random-effect & GLS regress: & & & Number & f obs & 515 \\
\hline Group variable & : ID & & & Number & f groups & 68 \\
\hline R-sq: within & $=0.3223$ & & & Obs pe & group: $\min =$ & 3 \\
\hline betweer & $=0.2808$ & & & & $\operatorname{avg}=$ & 7.6 \\
\hline overal. & $=0.3093$ & & & & $\max =$ & 8 \\
\hline & & & & Wald c & $2(10)$ & 232.83 \\
\hline $\operatorname{corr}\left(u_{-} i_{1}, x\right)$ & $=0$ (assumed & & & Prob > & hi2 & 0.0000 \\
\hline LV & Coef. & Std. Err. & $z$ & $\mathrm{P}>|\mathrm{z}|$ & [95\% Conf. & Interval] \\
\hline MB & -.1213129 & .0436384 & -2.78 & 0.005 & -.2068427 & -.0357831 \\
\hline EPS & .6185749 & .15724 & 3.93 & 0.000 & .3103902 & .9267596 \\
\hline IR & .9063269 & .2454584 & 3.69 & 0.000 & .4252373 & 1.387417 \\
\hline INF & -6.696664 & 1.711978 & -3.91 & 0.000 & -10.05208 & -3.341249 \\
\hline GDP & 36.5321 & 4.295112 & 8.51 & 0.000 & 28.11384 & 44.95037 \\
\hline LEV & .7222891 & .2336907 & 3.09 & 0.002 & .2642637 & 1.180314 \\
\hline PR & -.074301 & .0451326 & -1.65 & 0.100 & -.1627593 & .0141573 \\
\hline M1 & 1.008999 & .9133868 & 1.10 & 0.269 & -.7812063 & 2.799204 \\
\hline S & .2720432 & .0404049 & 6.73 & 0.000 & .192851 & .3512353 \\
\hline $\mathrm{ROA}$ & -1.518577 & .5331374 & -2.85 & 0.004 & -2.563507 & -.4736472 \\
\hline - cons & -7.662471 & 2.257061 & -3.39 & 0.001 & -12.08623 & -3.238712 \\
\hline sigma_u & .41739714 & & & & & \\
\hline sigma_e & .91197805 & & & & & \\
\hline rho & .17319431 & (fraction & & ce $d u$ & $\left.u_{-} i\right)$ & \\
\hline
\end{tabular}

Table 5 shows that the p-value for the ratio of the market value per share to the book value per share (MB) is equal to .005 which is too much less than the two significance levels $(0.01$ and 0.05$)$, indicating a highly statistically significant negative effect of the ratio of the market value per share to the book value per share (MB) on the value traded (natural logarithm of value traded). That means the higher the ratio of the market value per share to the book value per share (MB), the lower the value traded, as a proxy of stock liquidity, for industrial firms listed in the Amman Stock Exchange over the period from 2007 to 2014. The slope coefficient of the ratio of the market value per share to the book value per share (MB) of -.12, implying that a 1 unit increase in the ratio of the market value per share to the book value per share (MB) would have a decrease of .12 percent in the value traded, all other things being equal.

This result is inconsistent with the results of the study of (Madyan et al, 2013, Rubin, 2007, Blease, 2006 ) who find a statistically significant positive effect of the ratio of the market value per share to the book value per share on the stock liquidity. The higher the ratio of the market value per share to the book value per share, the higher the growth opportunities of the firm, and the higher the stock liquidity.

Table 5 also reports that the p-value for the earnings per share (EPS) is equal to .000 which is too much less than the two significance levels ( 0.01 and 0.05$)$, indicating a highly statistically significant positive effect of earnings per share (EPS) on the value traded ( natural logarithm of value traded). That means the higher earnings per share (EPS), the higher the value traded, as a proxy of stock liquidity, for industrial firms listed in the Amman Stock Exchange over the period from 2007 to 2014. The slope coefficient of the earnings per share (EPS) of .62, implying that a 1 unit increase 
in the earnings per share (EPS) would have an increase of .62 percent in the value traded, all other things being equal. This result is in line with the result of (Alnif, 2014; Xuan and Jonathan, 2010). The investors require less rate of return for high stock liquidity.

Table 5 reveals that the p-value for the interest rate (IR) is equal to .000 which is too much less than the two significance levels ( 0.01 and 0.05$)$, indicating a highly statistically significant positive effect of interest rate (IR) on the value traded ( natural logarithm of value traded). That means the higher the interest rate (IR), the higher the value traded, as a proxy of stock liquidity, for industrial firms listed in the Amman Stock Exchange over the period from 2007 to 2014. The slope coefficient of the interest rate (IR) of .91, implying that a 1 unit increase in the interest rate (IR) would have an increase of .91 percent in the value traded, all other things being equal. This result is consistent with the results of the study of Weston et al. (2005) who find a positive relationship between stock liquidity and interest rate.

Table 5 also shows that the p-value for the inflation rate (INF) is equal to .000 which is too much less than the two significance levels ( 0.01 and 0.05$)$, indicating a highly statistically significant negative effect of inflation rate (INF) on the value traded ( natural logarithm of value traded). That means the higher the inflation rate (INF), the lower the value traded, as a proxy of stock liquidity, for industrial firms listed in the Amman Stock Exchange over the period from 2007 to 2014. The slope coefficient of the inflation rate (INF) of -6.70 , implying that a 1 unit increase in the inflation rate (INF) would have a decrease of 6.70 percent in the value traded, all other things being equal.

This result is in line with the results of the study of Fujimoto (2003) who find a significant positive relationship between inflation rate and stock liquidity but inconsistent with the results of the study of Amador et al., 2011, and Goyenko and Ukhov, 2009 who find a negative relationship between inflation rate and stock liquidity.

Table 5 also shows that the p-value for the gross domestic product (GDP) is equal to .000 which is too much less than the two significance levels ( 0.01 and 0.05 ), indicating a highly statistically significant positive effect of the gross domestic product (GDP) on the value traded ( natural logarithm of value traded). That means the higher the gross domestic product (GDP), the higher the value traded, as a proxy of stock liquidity, for industrial firms listed in the Amman Stock Exchange over the period from 2007 to 2014. The slope coefficient of the gross domestic product (GDP) of 36.5, implying that a 1 unit increase in the gross domestic product (GDP) would have an increase of 36.5 percent in the value traded, all other things being equal. This result is consistent with the results of the study of Chordia et al., 2001.

Table 5 demonstrates that the p-value for the financial leverage (LEV) is equal to .002 which is too much less than the two significance levels ( 0.01 and 0.05$)$, indicating a statistically highly significant positive effect of the financial leverage (LEV) on the value traded ( natural logarithm of value traded). That means the higher the financial leverage (LEV), the higher the value traded, as a proxy of stock liquidity, for industrial firms listed in the Amman Stock Exchange over the period from 2007 to 2014. The slope coefficient of the financial leverage (LEV) of .72, implying that a 1 unit increase in the financial leverage (LEV) would have an increase of .72 percent in the value traded, all other things being equal.

This result is consistent with the results of the study of Hansen and Sungsuk (2013) Frieder, L., and R. Martell., 2006, Jensen, M., 1986, who find a positive relationship between financial leverage and stock liquidity, where using debt in the capital structure encourage firms' managers to make good investment decisions. In contrast this result is inconsistent with the results of the study of Lipsona and Mortal, 2009, who find that the stock liquidity is negatively affected by financial leverage where firm that has high leverage has low stock liquidity and depends highly on issuing stocks to finance its operations, so firm can reduce its cost of capital as well as its return by improving stock liquidity through declining the ratio of debt in its capital structure. On the other hand, Alnif, 2014 find that the stock liquidity is not affected by financial leverage.

Table 5 also shows that the p-value for the dividend payout ratio (PR) is equal to .100 which is greater than the two significance levels (0.01 and 0.05), indicating a statistically insignificant negative effect of the dividend payout ratio (PR) on the value traded (natural logarithm of value traded). That is, the value traded (natural logarithm of value traded) for industrial firms listed in the Amman Stock Exchange is not affected by the dividend payout ratio (PR).

This result is inconsistent with the results of the study of Spindt et al. (2007). Who find that stock liquidity is negatively affected by the dividend payout ratio where firms with high stock liquidity try to pay lower cash dividends as well as stockholders try to hold the shares of firms that pay high dividends.

Table 5 shows that the p-value for the money supply (M1) is equal to .269 which is too much greater than the two significance levels (0.01 and 0.05 ), indicating a statistically insignificant positive effect of the money supply (M1) on the value traded (natural logarithm of value traded). That is, the value traded (natural logarithm of value traded) for 
industrial firms listed in the Amman Stock Exchange is not affected by the money supply (M1).

This result is consistent with the results of the study of Weston et al. (2005); Chordia et al. (2005); Goyenko and Ukhov (2009); Amador, 2011, who find a positive relationship between the growth in the money supply and stock liquidity, where the higher the growth in the money supply (expansionary monetary policy) the higher the stock liquidity. In contrast, the lower the growth in the money supply (tightening monetary policy) the higher the illiquidity.

Table 5 also shows that the p-value for the size of the firm (S) is equal to .000 which is too much less than the two significance levels $(0.01$ and 0.05$)$, indicating a highly statistically significant positive effect of the size of the firm (S) on the value traded ( natural logarithm of value traded). That means the higher the size of the firm (S), the higher the value traded, as a proxy of stock liquidity, for industrial firms listed in the Amman Stock Exchange over the period from 2007 to 2014. The slope coefficient of the size of the firm (S) of .27, implying that a 1 unit increase in the size of the firm (S) would have an increase of .27 percent in the value traded, all other things being equal.

This result is consistent with the results of the study of Shuenn (2007); and Rezaei and Aliahmadi (2015); (Alnif, 2014). Stoll (2000), Madyan, 2013, where the financial analysts and stockholders pay more attention to the large firms as well as large firms can decline the information asymmetry and increasing liquidity by disclosing more information. In addition, the shares of large firms can be traded more easily, quickly, and without a significant loss of value than the shares of small firms. Further, the information on the large firms can be readily accessible and flow than the information on small firms.

Finally, Table 5 shows that the p-value for the return on assets (ROA) is equal to .004 which is too much less than the two significance levels (0.01 and 0.05$)$, indicating a highly statistically significant negative effect of the return on assets (ROA) on the value traded ( natural logarithm of value traded). That means the higher the return on assets (ROA), the lower the value traded, as a proxy of stock liquidity, for industrial firms listed in the Amman Stock Exchange over the period from 2007 to 2014. The slope coefficient of the return on assets (ROA) of -1.52 , implying that a 1 unit increase in the return on assets (ROA) would have a decrease of 1.52 percent in the value traded, all other things being equal.

This result is consistent with the results of the study of (alnaif, 2014), Asle et al. (2013), who find a negative relationship between return on assets (ROA) and stock liquidity, where the investors with high return on assets firms could hold their stocks and they do not desire to sell them which in turn leads to decrease the stock liquidity. In contrast, this result is inconsistent with the results of the study of Hansen and Sungsuk (2013); Rezaei and Alijani; Niloofar Rezaei and Saeid Aliahmadi (2015), who find that the stock liquidity is positively affected by the return on assets (ROA).

Table 6. Model summary

\begin{tabular}{|c|c|c|c|c|c|}
\hline Model & $\mathrm{R}$ & R Square & $\begin{array}{l}\text { Adjusted } \\
\text { R Square }\end{array}$ & $\begin{array}{l}\text { Std. Error of the } \\
\text { Estimate }\end{array}$ & Durbin-Watson \\
\hline 1 & $.556^{\mathrm{a}}$ & .310 & .296 & .995980943717276 & 1.832 \\
\hline
\end{tabular}

As can be seen from Table 6, that about 30 percent of the variation in the value traded ( natural logarithm of value traded) is explained by the linear relationship between (interest rate, inflation, monetary policy, GDP, market to book ratio, earnings per share, size, dividends, financial leverage, return on assets) as independent variables and the value traded ( natural logarithm of value traded), while 70 percent of the variability in the value traded ( natural logarithm of value traded) caused by external factors.

It can be also seen from Table 6 that the value of the Durbin-Watson (1.832), which is used to detect the problem of autocorrelation) is close to two, implying that there is no autocorrelation between the error terms.

\section{Summary and Conclusions}

The aim of this study is to identify the factors (macroeconomics and firm-specific) that determine the stock liquidity for all industrial firms listed in the Amman Stock Exchange over the period from 2007 to 2014.

The results show a highly statistically significant negative effect of the ratio of the market value per share to the book 
value per share (MB) on the value traded (natural logarithm of value traded). That means the higher the ratio of the market value per share to the book value per share (MB), the lower the value traded, as a proxy of stock liquidity, for industrial firms listed in the Amman Stock Exchange over the period from 2007 to 2014.

A highly statistically significant positive effect of earnings per share (EPS) on the value traded (natural logarithm of value traded). That means the higher earnings per share (EPS), the higher the value traded, as a proxy of stock liquidity, for industrial firms listed in the Amman Stock Exchange over the period from 2007 to 2014. So, the investors require less rate of return for high stock liquidity.

A highly statistically significant positive effect of interest rate (IR) on the value traded (natural logarithm of value traded). That means the higher the interest rate (IR), the higher the value traded, as a proxy of stock liquidity, for industrial firms listed in the Amman Stock Exchange over the period from 2007 to 2014.

A highly statistically significant negative effect of inflation rate (INF) on the value traded (natural logarithm of value traded). That means the higher the inflation rate (INF), the lower the value traded, as a proxy of stock liquidity, for industrial firms listed in the Amman Stock Exchange over the period from 2007 to 2014.

A highly statistically significant positive effect of the gross domestic product (GDP) on the value traded (natural logarithm of value traded). That means the higher the gross domestic product (GDP), the higher the value traded, as a proxy of stock liquidity, for industrial firms listed in the Amman Stock Exchange over the period from 2007 to 2014.

A highly statistically significant positive effect of the financial leverage (LEV) on the value traded (natural logarithm of value traded). That means the higher the financial leverage (LEV), the higher the value traded, as a proxy of stock liquidity, for industrial firms listed in the Amman Stock Exchange over the period from 2007 to 2014. This result is consistent with the results of the study of Hansen and Sungsuk (2013) Frieder, L., and R. Martell., 2006, Jensen, M., 1986, who find a positive relationship between financial leverage and stock liquidity, where using debt in the capital structure encourage firms' managers to make good investment decisions. In contrast this result is inconsistent with the results of the study of Lipsona and Mortal, 2009, who find that the stock liquidity is negatively affected by financial leverage where firm that has high leverage has low stock liquidity and depends highly on issuing stocks to finance its operations, so firm can reduce its cost of capital as well as its return by improving stock liquidity through declining the ratio of debt in its capital structure. On the other hand, Alnif, 2014 find that the stock liquidity is not affected by financial leverage.

A statistically insignificant negative effect of the dividend payout ratio (PR) on the value traded (natural logarithm of value traded). That is, the value traded (natural logarithm of value traded) for industrial firms listed in the Amman Stock Exchange is not affected by the dividend payout ratio (PR).

A statistically insignificant positive effect of the money supply (M1) on the value traded (natural logarithm of value traded). That is, the value traded (natural logarithm of value traded) for industrial firms listed in the Amman Stock Exchange is not affected by the money supply (M1).

A highly statistically significant positive effect of the size of the firm (S) on the value traded (natural logarithm of value traded). That means the higher the size of the firm (S), the higher the value traded, as a proxy of stock liquidity, for industrial firms listed in the Amman Stock Exchange over the period from 2007 to 2014. This result is consistent with the results of the study of Shuenn (2007); and Rezaei and Aliahmadi (2015); (Alnif, 2014). Stoll (2000), Madyan, 2013, where the financial analysts and stockholders pay more attention to the large firms as well as large firms can decline the information asymmetry and increasing liquidity by disclosing more information. In addition, the shares of large firms can be traded more easily, quickly, and without a significant loss of value than the shares of small firms. Further, the information on the large firms can be readily accessible and flow than the information on small firms.

Finally, a highly statistically significant negative effect of the return on assets (ROA) on the value traded (natural logarithm of value traded). That means the higher the return on assets (ROA), the lower the value traded, as a proxy of stock liquidity, for industrial firms listed in the Amman Stock Exchange over the period from 2007 to 2014. This result is consistent with the results of the study of (alnaif, 2014), Asle et al. (2013), who find a negative relationship between return on assets (ROA) and stock liquidity, where the investors with high return on assets firms could hold their stocks and they do not desire to sell them which in turn leads to decrease the stock liquidity. In contrast, this result is inconsistent with the results of the study of Hansen and Sungsuk (2013); Rezaei and Alijani; Niloofar Rezaei and Saeid Aliahmadi (2015), who find that the stock liquidity is positively affected by the return on assets (ROA).

Based on the above results regarding the determinants of the stock liquidity in the context of Jordan, we recommend the future research to: (1) carry out a similar study in some developing countries similar to Jordanian market for comparison purposes, (2) examine the factors that affecting stock liquidity by using monthly data, (3) investigate the 
impact of exchange rate, as macroeconomics variable, on stock liquidity.

\section{References}

Alnaif, K. (2014). Stock Liquidity Determination: Evidence from Amman Stock Exchange. Asian Economic and Financial Review, 4(12), 1894-1905.

Amador, O., G"achter, M., Larch, M., \& Peter, G. (2011). Monetary policy and its impact on stock market liquidity: Evidence from the euro zone. Working Papers in Economics and Statistics.

Amihud, Y. (2002). Illiquidity and Stock Returns: Cross Section and Time Series Effects. Journal of Financial Markets, 5(2), 31-56.

Amihud, Y., \& Mendelson, H. (1988). Liquidity and asset price: financial management implications. Financial Management, 17(1), 5-15.

Amihud, Y., \& Mendelson, H. (1989). The Effects of Beta, Bid-Ask Spread, Residual Risk, and Size on Stock Returns. The Journal of Finance, 44, 479-486.

Amihud, Y., \& Mendelson, H. (2000). The liquidity route to a lower cost of capital. Journal of Applied Corporate Finance, 12(4), 8-25.

Asle, H., Valahzaghard, M., \& Ahranjani, B. (2013). A survey on the relationship between stock liquidity with firm performance: A case study of Tehran stock exchange. Management Science Letters, 3(2), 635-640.

Blease, J., \& Paul, D. (2006). Stock Liquidity and Investment Opportunities: Evidence from Index Additions. Financial Management, 35(3), 35-51.

Brennan, M., Chordia, T., \& Subrahmanyam, A. (1998). Alternative Factor Specifications, Security Characteristics, and the Cross-Section of Expected Stock Returns. Journal of Financial Economics, 49(3), 345-373.

Brockman, P., Howe, J., \& Mortal, S. (2008). Stock market liquidity and the decision to repurchase. Journal of Corporate Finance, 14, 446-459. http://dx.doi.org/10.1016/j.jcorpfin.2008.06.001

Chai D, Faff, R., \& Gharghori, P. (2010). New evidence on the relation between stock liquidity and measures of trading activity. International Review of Financial Analysis, 19(3), 181-192.

Chordia, T., Roll, R., \& Subrahmanyam, A. (2001). Market liquidity and Trading Activity. Journal of Finance, 56(2), 501-530. http://dx.doi.org/10.1111/0022-1082.00335

Chordia, T., Sarkar, A., \& Subrahmanyam, A. (2005). The Joint Dynamics of Liquidity, Returns, and Volatility across Small and Large Firms. Federal Reserve Bank of New York Staff Reports, 207. Retrieved from http://www.newyorkfed.org/research/staff_reports/sr207.pdf

Frieder, L., \& Martell, R. (2006). Capital Structure and The Liquidity of a Firm's Stock, Working paper, Purdue University.

Fujimoto, A. (2003). Macroeconomic sources of systematic liquidity. Unpublished working paper, Yale University.

Goyenko, R., \& Ukhov, A. (2009). Stock and bond market liquidity: A long-run empirical analysis. Journal of Financial and Quantitative Analysis, 44(1), 189-212.

Grecuhina, K., \& Timofejeva, M. (2008). The impact of Liquidity providers on the Baltic Stock Exchange. Unpublished Bachelor Thesis, Stockholm University.

Hansen, S., \& SungSuk, K. (2013). Influence of Stock Liquidity to Firm Value in Indonesian Stock Market. The 2013 IBEA, International Conference on Business, Economics, and Accounting, 20 - 23 March 2013, Bangkok Thailand.

Jacoby, G., Fowler, D., \& Gateman, A. (2000). The Capital Asset Pricing Model and the Liquidity Effect: A Theoretical Approach. Journal of Financial Markets, 3(1), 69-81.

Jensen, M. (1986). Agency cost of free cash flow, corporate finance and takeovers. American Economic Review Papers and Proceedings, 76, 323-329.

Kumar, G., \& Misra, K. (2015). Closer View at the Stock Market Liquidity: A Literature Review. Asian Journal of Finance \& Accounting, 7(2), 35-57.

Lesmond, D., O'connor, P., \& Senbet, L. (2008). Capital structure and equity liquidity. Working Paper, Tulane University. 
Lipson, M., \& Mortal, S. (2009). Liquidity and Capital Structure. Journal of Financial Markets, Forthcoming; Darden Business School Working Paper. Retrieved from http://ssrn.com/abstract=887413

Madyan, M., Salim, U., Anshori, M., \& Solimun. (2013). Liquidity Determinants of Sharia and non Sharia Stocks. IOSR Journal of Business and Management, 9(2), 219-248.

Moghadas, F. (2011). Effect of financial constraints on investment decisions of the firms listed in Tehran stock exchange. Unpublished master thesis, Isfahan University.

O'Hara, M. (1998). Market microstructure theory. Oxford: Blackwell.

Rezaei, F., \& Alijani, T. (2013). A Review of the Relationship between Earnings Management and Companies' Stock Liquidity. Journal of Basic and Applied Scientific Research, 3(10), 306-315.

Rezaei, N., \& Aliahmadi, S. (2015). Asset Liquidity, Stock Liquidity and Investment Decisions. Indian Journal of Fundamental and Applied Life Sciences, 5(S4), 120-129.

Rubin, A. (2007). Ownership Level, Ownership Concentration, and Liquidity. Journal of Financial Market, 10, 219-248.

Shuenn, R. (2007). A Study on the Factors Affecting Stock Liquidity. International Journal of Services and Standards, 3(4), 453-475.

Spindt, P., Banerjee, S., \& Gatchev, V. (2007). Stock Market Liquidity and Firm Dividend Policy. Journal of Financial and Quantitative Analysis, 42(2), 369-397. Retrieved from http://www.jstor.org/stable/27647301

Stoll, H. (2000). Friction. Journal of Finance, 55(4), 1479-1514.

Udomsirikul, P., Jamreornvong, S., \& Jiraporn, P. (2011). Liquidity and capital structure. Journal of Multinational Financial Management, 96(2) 215-237.

Weston, J.P., Butler, A.W., \& Grullon, G. (2005). Stock Market Liquidity and the Cost of Issuing Equity. Journal of Financial and Quantitative Analysis, 40(2), 331-348. Retrieved from http://www.jstor.org/stable/27647200

Xuan, V., \& Jonathan, V. (2010). An empirical investigation of liquidity and stock returns relationship in Vietnam stock markets during financial crisis. MPRA Paper No. 29862, Posted 29. Retrieved from http://mpra.ub.uni-muenchen.de/29862/ 